\title{
Do Dietary Changes Increase the Propensity of Food Riots? An Exploratory Study of Changing Consumption Patterns and the Inclination to Engage in Food-Related Protests
}

\author{
Alexander F. Legwegoh ${ }^{1}$, Evan D. G. Fraser ${ }^{1, *}$, Krishna Bahadur KC ${ }^{1}$ and \\ Philip Antwi-Agyei ${ }^{2}$
}

1 Department of Geography, University of Guelph, Hutt Building Room 123, 50 Stone Road East Guelph, ON N1G 2W1, Canada; E-Mails: alegwego@uoguelph.ca (A.F.L.); krishnak@uoguelph.ca (K.B.KC)

2 Department of Environmental Science, College of Science, Kwame Nkrumah University of Science and Technology, Private Mail Bag, University Post Office, Kumasi, Ghana;

E-Mail: pantwi-agyei.sci@knust.edu.gh

* Author to whom correspondence should be addressed; E-Mail: frasere@uoguelph.ca; Tel.: +233-519-824-4120 (ext. 53011).

Academic Editor: Marc A. Rosen

Received: 4 August 2015 / Accepted: 14 October 2015 / Published: 20 October 2015

\begin{abstract}
Following widespread food riots in 2008, many people argued that high food prices cause political instability and civil unrest in the form of food riots. However, subsequent research has demonstrated that political, cultural, and economic factors confound the impact of price in determining whether a food riot occurs. This paper contributes to this growing body of literature by exploring: (1) the relationship between household demographic characteristics and reported intent to riot due to future food price rises; and (2) the relationships between people's diets and their reported intent to riot due to future food price rises. We hypothesize that local context, including demographic factors and dietary patterns, combine to predispose some groups of people to riot when food prices rise. This hypothesis is tested using household surveys $(N=300)$ and three focus groups discussions $(N=65)$ carried out in three cities in the Central African nation of Cameroon that experienced widespread food riots in 2008 . Results show that some $70 \%$ of the respondents would riot if food prices went up. Also, in the event of food price rises: (1) households in Cameroon's major cities are more likely to riot than the citizens of smaller cities; (2) Households with relatively higher educational level, high incomes, are less likely to riot. Finally, the
\end{abstract}


relationship between dietary patterns and propensity to riot is not straightforward as changes in consumption of different food groups influence propensity to riot in different ways. Overall, this paper demonstrates that preemptive strategies designed to avoid future food riots in Cameroon must take into consideration these spatial, demographic, and dietary factors.

Keywords: food riots; food prices; diets; consumption changes; urban food insecurity; Cameroon

\section{Introduction}

Many authors argue that high, food prices cause food riots, and point to the food price inflation and wide spread food riots of 2008 as evidence for this relationship [1-4]. A closer inspection of the events from 2008 reveals a number of other factors beyond just the share price of food increases the likelihood that a sudden or drastic change in price would lead to riots. First, there is a very poor correlation between places in the world where food is expensive and places where rioting happened. For example, in Figure 1, we see that in sub-Saharan Africa (SSA), countries such as Angola, Botswana, Nigeria, and Ghana have consistently higher consumer prices indices than Cameroon, Ivory Coast, and South Africa. Nevertheless, there were no riots in the former countries while the latter experienced widespread problems. Second, when we look in detail at food prices in places where rioting occurred, we see that it was mostly imported foods that became more expensive while domestic food prices stayed level. Third, careful analyses of the events in 2008 suggest that perceptions of unfair politics and corrupt economics may have been more important than hunger or desperation in creating the momentum that led to the food riots [4]. Such arguments have led a number of scholars to argue that assuming a causal relationship between rising food prices and civil unrest is simplistic and that more detailed research is needed to unpack the ways in which food price rises trigger riots [1,5-7].

For instance, there were widespread food riots in many countries in the global south in 2008, but it was mostly grains that were affected by rising prices. Indeed, when global wheat prices doubled in the year leading up to April 2008, and rice prices more than doubled between January and April 2008, social unrest hit several cities including Douala (Cameroon), Ouagadougou (Burkina Faso), and Dakar (Senegal) [2]. Interestingly, there were no recorded crop failures across SSA in 2008, and by all accounts that year seems to have been reasonably productive for the region [8]. Significantly, however, most of the rice and wheat (wheat flour) that are consumed in these countries are imported rather than locally produced $[9,10]$. This suggests that the type of food people eat, and whether they rely on imported versus local foodstuffs, may be significant in determining a propensity to riot. 
A

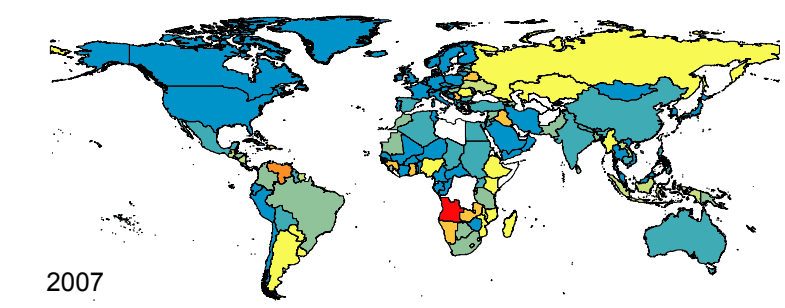

B

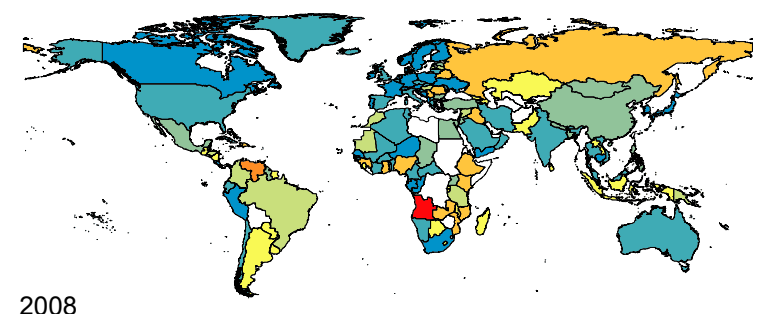

C

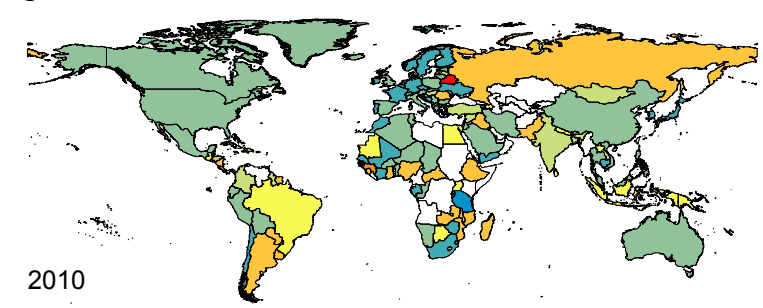

D

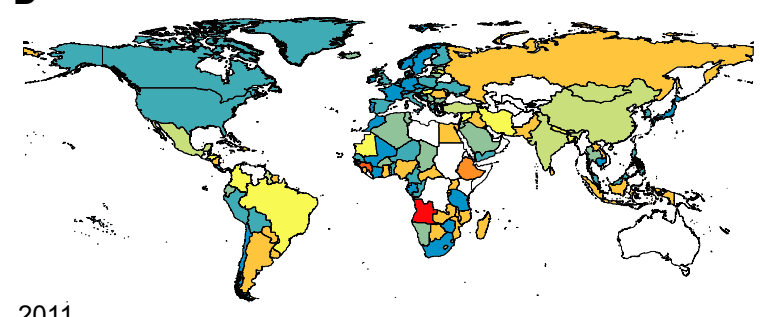

E Consumer price index

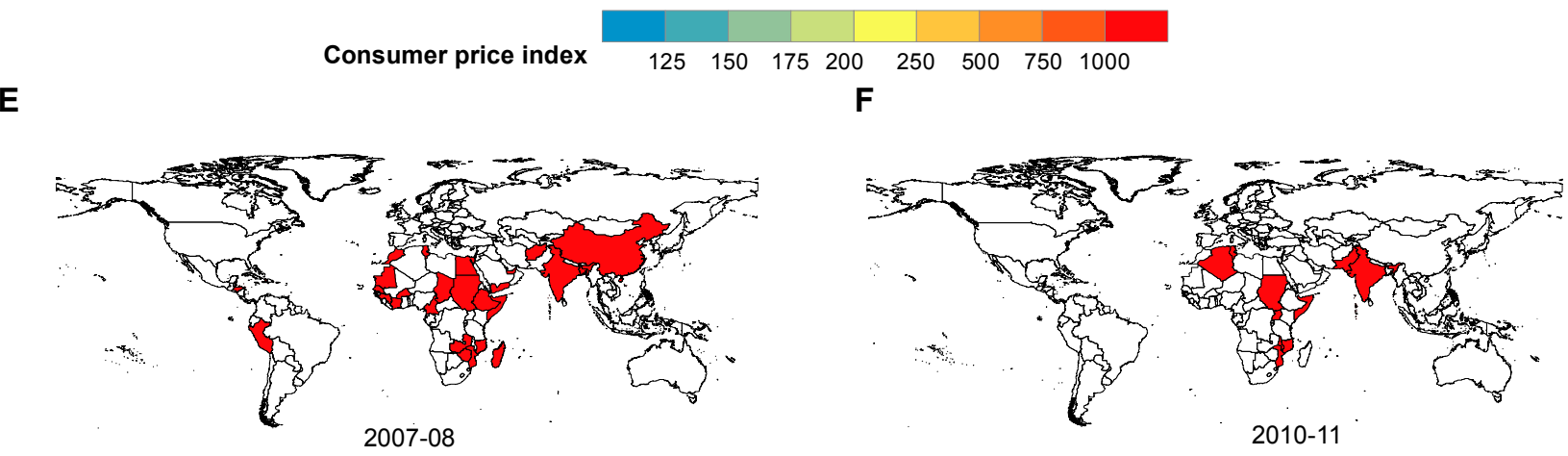

2007-08

2010-11

Evidence of food riots

Figure 1. Panels (A), (B), (C) and (D) show the consumer price index for food [11]. Panels (E) and (F) show the location of food riots in 2008 and 2011 [12]. Note the lack of correlation between places where food prices are high and where food riots occurred.

The purpose of this paper is to contribute to the growing body of literature that tries to explore the conditions under which food price rises trigger riots. In particular, this paper asks: "is there something significant about imported foods that make the link between their prices or availability and riots more obvious?" This is an important question to ask since better unpacking and understanding the specific ways that price rises cause riots is vital to understanding how the world will adapt to the higher and more volatile food prices that many experts think will be a hallmark of the 21st century [13]. More specifically, this paper presents the results from survey and focus group data collected in three Cameroonian cities where we asked respondents questions that explored:

(1) the relationship between household demographic characteristics and reported intent to riot due to future food price rises;

(2) the relationships between diets/dietary changes and reported intent to riot due to future food price rises. 


\section{Theory/Literature}

While many food security scholars have written about a possible connection between food price rises and food riots [3,5], a considerable body of work rejects the hypothesis that "a hungry man is an angry man" (see, for example, Jack Goldstones work on theories of revolution [14-18]). In particular, the history of food security illustrates that even during the world's worst famines, the poorest tend to suffer in silence and rarely (if ever) protest the system that is causing their starvation. For example, there were no reports of food riots in 1943 as 7 million Bengalis and Burmese refugees died due to starvation [19]. Similarly, in studies on Ethiopia, which has been plagued with repeated famine episodes [20], we have been unable to uncover evidence of food riots (defined in this paper as any form of civil-strife, demonstration or protest against the government or food merchants, that is catalyzed by discontent about the inaccessibility of food).

As a result, O'Brien [21] notes that food riots are more than simply a product of unmet demands for food. Instead, some scholars argue that food riots are better understood as sudden, unexpected events that may trigger a range of social grievances such as demands for social, political, and economic rights. Many argue that food, therefore, is more of a catalyst than a cause and may be the proverbial "last straw" that brings to the forefront other discontents that plague a society [4].

Goldstone goes even further, and puts food riots within the broader context of revolutions. In particular, he argues that, in situations where food riots cascade into wholesale revolutions (such as the Arab Spring or the French Revolution), the food price rise is simply a trigger that gives voice to the citizenry's anger at unjust and inept governments. Typically, this often happens in urban areas, or in societies experiencing rapid urbanization. Furthermore, food price rises help trigger revolutions by giving alienated elites a cause to cooperate thus ensuring a broad based mobilization of entire populations. Food price increases also may lead to a refusal by the international community to support the government [18] (p. 8).

However, according to Bentley [22], much of the just-cited research that tries to develop a theoretical understanding of food riots risks losing sight of the importance of food altogether. Instead, Bentley argues that research on food riots needs to involve a sustained cultural analysis of the food itself as one key way of developing an understanding of how and why food riots occur. Bentley shows that the anger expressed during food riots is often centered on one food item such as bread or rice. Normally, these are staples and integral to the cultures cuisine, consumed by both the rich and poor alike and become the symbol of people's intense frustration and anger at the broader system that make this food inaccessible [22]. For example, the 1917 New York food riots illustrate the importance of staple foods. In this case, prices rose for chicken, potatoes, and onions. The cultural and religious importance of these food for newly immigrated Jewish households, as well as the fact that in these households these foods were traditionally perceived as "last resort" foods are both important considerations in understanding why people chose to riot at this time [22,23]. More recently, it is significant that many political protests around food have been named after the foodstuffs central to affected people (e.g., the pasta protests of Italy, the Mexican tortilla riots, or bread riots in Egypt [24-26]).

In summary, we take from this brief exploration of the food riots scholarship two key arguments: (1) food price increases may act as a trigger or catalyst for riots, since they expose deep-seated political problems; and (2) if the price of foods that are of functional or symbolic importance increases, then people are more likely to react violently. Therefore, we conclude this theoretical review by 
reflecting on an often-used quotation in food studies that "food is good to think with" [27]. More specifically, this paper begins with the premise that people's experiences with, and preferences for, certain foodstuffs, as well as the practical properties of these foods (including the cost, shelf life, taste, etc.) need to be evaluated alongside a deeper political understanding of different societies. It is only by bringing these themes explicitly together that we can develop a fully realized theoretical understanding of the causes of food riots.

\section{Methodology}

In order to explore these complex issues, we adopted a mixed-method approach where we are intentionally trying to bring qualitative and quantitative insights into a comprehensive explanatory framework to provide both a preliminary understanding of the trends but also the nuances that go behind creating the conditions that lead to a food riot [28]. In doing this, we concur with proponents of mixed methodology as an essential approach to understanding social phenomenon, given that it provides an opportunity to triangulate or "validate research findings by generating and comparing different sorts of data, and different respondents perspectives, on the topic under investigation" [29] (p. 111). Our data collection tools (survey and focus group) were intentionally designed to collect both quantitative and qualitative insights on diverse issues that shaped peoples' perspectives on, and reactions to, food price changes. Thus, through our analysis, we have tried to provide a holistic account of the situation in Cameroon that led to the food riots of 2008 and how we can learn from this situation to inform policy making.

\subsection{Selection of Cities}

Our research focuses on urban areas in Cameroon, which were chosen as our case study for two reasons: (1) Cameroon is rapidly urbanizing, and according to UN Habitat is 62\% urbanized as of 2015 [30] and a large proportion of the population now being net buyers of food; (2) urban Cameroon was the location of significant civil disorder around food prices in 2008.

In terms of a research design, we classified cities in Cameroon along an agricultural continuum that reflects Bopda and Awonos ideas that all cities in the region have a degree of an agricultural background [31]: First were those cities well integrated into the global economy and with limited amounts of agricultural production within their boundaries; Second are cities that while integrated into global markets also maintained a robust urban and peri-urban agricultural system given a large amount of undeveloped land; Third are urban communities further in the hinterlands where it takes significantly longer for imported food (and price signals) to be transmitted. This third type of city is largely serviced by fluid rural-urban supply chains as well as by intensive commercial farms units within the city or in close proximity (peri-urban) to the city. Along this continuum in Cameroon, Douala, the economic capital and major port city in Cameroon was chosen as representing the first category, Buea and its satellite towns (Muea, Bomaka, Mile 17, and Mile 16) were selected to represent the second category while Bamenda was selected for the third category (Figure 2). 


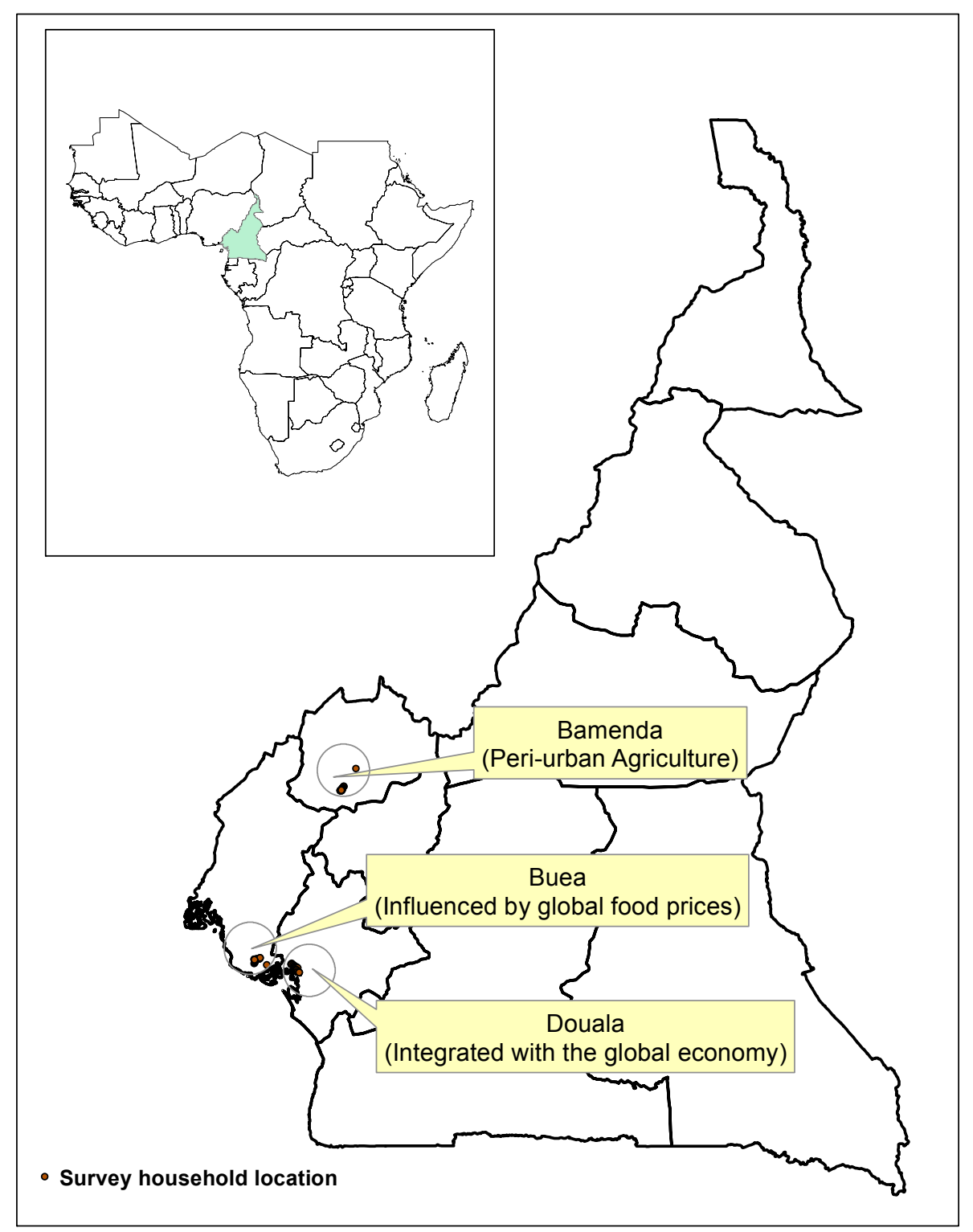

Figure 2. Map of Cameroon showing three study sites: Douala, which is integrated within the global economy; Buea, which is influenced by global food prices and Bamenda, which has a robust urban and peri-urban agricultural system.

\subsection{Sampling}

For the surveys, a random sample of 100 participants was selected from each case study city making a total of 300 participants $(n=300)$. In each city, participants were selected in four neighborhoods randomly from a list of neighborhoods in each city. Within each neighborhood the first house on the main street was selected then every alternate household etc. At the household level, household heads were requested to answer the questions on the survey or to assign a member of their household who had knowledge of household socio-economic status and dietary patterns to respond to the questions.

We also carried out three focus group discussions in Buea and Muea area- two of these were women only groups, one with 25 members, another with 10 members and the other was a mixed male/female group of 30 members. These were already preexisting community associations who agreed to create time within their regular meeting agenda to accommodate a focus group discussion on the issue of 
food prices. The focus groups were designed to explore people's perception and reaction to food price rises, their food preference, diets, and changes in their dietary patterns as well as what they thought could be potential solutions to food insecurity within their community. All data was collected in June 2014 by one of the authors and group of six trained research assistants.

\subsection{Survey Design}

Surveys were designed to capture data on the following topics:

- Household demographics including age, education levels, indicators of relative wealth, and levels of social, economic, and political satisfaction.

- Household food preference (this was done without any predetermined list of food allowing us to collect qualitative data on the range of food preferences amongst respondents.)

- A $24 \mathrm{~h}$ dietary diversity survey commonly used in food security measurement $[32,33]$.

o The survey asks if people have eaten (yes/no) from the 12 food groups listed below. The resultant household dietary diversity score (HDDS) were values between 0 and 12, which represented the total number of food groups consumed by members of the household within the last $24 \mathrm{~h}$. The food categories are:

a. Cereals (bread, rice noodles, biscuits or foods made from millet, sorghum, maize, rice, wheat)

b. Tuber or roots (potatoes, yams, manioc, cassava)

c. Vegetables

d. Fruits

e. Meat (beef, pork, lamb, goat, rabbit, game, chicken, duck, other birds, offal)

f. Eggs

g. Fish/shellfish

h. Pulses/legumes/nuts (beans, peas, lentils, or other nuts)

i. Milk (and milk products)

j. Oil/fat (foods made with oil, fat, or butter)

k. Sugar/ honey

1. Condiments, coffee and tea

- Using $24 \mathrm{~h}$ recall as the basis, we asked if the consumption of each of the 12 food groups had increased, stayed the same or decreased since childhood (henceforth referred to as "over time").

- Building on the same food groups identified above, we asked how households reacted to food prices changes in the past. In particular, we asked whether households decreased, maintain the same quantity or increased the quantities of these specific foods during the 2008 price shock. We also followed up with an open-ended request for more specific examples of dietary change and the reasons behind the changes.

- We asked the participants to tell us whether or not they would engage in some kind of political protest in the event of another food price rise in Cameroon. We then went further to ask the type of political action they would take including: signing a petition, join a boycott, attending a peaceful manifestation or join a strike action. Finally, to explore which places (cities/towns) in Cameroon were thought to be more prone to riots and why, we asked the participants to tell us 
where they thought people would most likely engage in a food riot/protest and why they believed those people/places would be most reactive.

\subsection{Preparation of Variables}

While most of the data were collected in a way that could be directly analyzed, some of the variables needed to be transformed into indices. In particular:

We calculated a weighted education index (WEI) by adding all household members weighted educational attainment score. To do this, each household member was scored: no education $=0.00,1-5$ years of schooling $=0.25,6-8$ years of schooling $=0.50,9-12$ years of schooling $=0.75$ and postsecondary $=1.00$ (see details in [34]).

To create a wealth ranking, we drew on the results of two questions in our survey. First we asked households to assess their living standard by inquiring, "On a scale from 1 to 10, where would you place the current living standards of your household? Where 1 is very poor and 10 is very wealthy". Second, we asked "How do you think your living standard compares with that found in the average home in your city?" We recoded the results as follows: for those who self-reported their living standards as between 1 to 3 , we gave them a score of 1.4 to 6 scored 2 and 7 to 10 scored 3 . While for the comparative living standard question we recoded answers with a 4 or 5 as "below average", 2 or 3 as "average", and 1 as above average. Below average received 1 point, average 2 points, and above average 3 points. To create the final wealth score, we summed the two scores and ranked people according to the score where score of: 2 and 3 =Low income; 4 and 5 = Middle income; $6=$ Upper middle income. To verify the resultant score, we did a qualitative comparison between the score (wealth ranking) and the recorded profession of the respondents and other household members and found a close match between the two. These calculations are presented in Table 1.

Table 1. Developing a wealth ranking for the sample.

\begin{tabular}{|c|c|c|c|c|c|}
\hline \multicolumn{4}{|c|}{ Survey Questions } & \multicolumn{2}{|c|}{ Wealth Ranking } \\
\hline \multicolumn{2}{|c|}{$\begin{array}{l}\text { On a scale from } 1 \text { to } 10, \\
\text { where would you place the } \\
\text { current living standards of your } \\
\text { household? Where } 1 \text { is "very } \\
\text { poor" and } 10 \text { is "very wealthy" }\end{array}$} & \multicolumn{2}{|c|}{$\begin{array}{l}\text { How do you think your living standard } \\
\text { compares with that found in the } \\
\text { average home in your city? }\end{array}$} & & \\
\hline Actual score & Adjusted score & Actual score & Adjusted score & $\begin{array}{l}\text { Total score (sum of } \\
\text { two adjusted scores) }\end{array}$ & Income level \\
\hline $1-3$ & 1 & $\begin{array}{c}\text { Far below average } \& \\
\text { below average }\end{array}$ & 1 & $2 \& 3$ & Low income \\
\hline $4-6$ & 2 & Average & 2 & $4 \& 5$ & Middle income \\
\hline $7-10$ & 3 & $\begin{array}{l}\text { Above average and } \\
\text { far above average }\end{array}$ & 3 & 6 & $\begin{array}{l}\text { Upper middle } \\
\text { income }\end{array}$ \\
\hline
\end{tabular}




\subsection{Data Analysis through Descriptive Statistics and Logistic Regression Model}

Data were analyzed in SPSS version 22 [35] and STATA 13 [36]. Our qualitative data were read through carefully and coded using hyper Research 3.7.2 [37] for emerging themes. In terms of our statistical work, our basic approach had two steps:

First, we identified households who expressed a propensity to riot or not and explored whether rates were different in the three cities we collected data from. To explore the possible associations between riots and household demographic characteristics, we divided participants into two groups: (1) those who noted that they would riot; and (2) those who reported that they would not riot if food prices were to go up. We then explored if there were differences in location, wealth, education, or other household characteristics between these two groups. A chi-squared test determined whether there were statistically significant associations between a propensity to riot and the demographic variables.

Second, we tested the hypothesis that differences in (1) food consumption behavior; and (2) changes in food consumption behavior may create a greater propensity to riot. To do this, we used a Logit Modelling Approach (Equation (1)), which is a statistical tool designed to deal with data where the dependent variable is dichotomous (e.g., would you riot: YES/NO). To accomplish this, we first computed a dichotomous variable that indicated whether the participant would participate at a riot or not (that is, 1 , if participant expressed a propensity to riot or 0 , otherwise) and used the following equation for the LOGIT model:

$$
\operatorname{logit}(\mathrm{p})=\ln \left(\frac{p}{1-p}\right)=\beta \mathrm{o}+\beta \mathrm{i} \sum_{i=1}^{n} X i
$$

In this equation logit $(\mathrm{p})=$ the probability that a respondent would participate at a riot. The propensity index for any given participant depends on a vector of explanatory variables $(X i)$ pertaining to that household. We used this approach to develop a model that explains how likely a respondent is to participate at a riot.

In this model, $X i$ were the predictor variables that included: age range, price increase $(1=$ yes, $0=$ no), total expenditure (US\$), weighted education index (WEI), wealth rank, expenditure on food and groceries (US\$), and change in consumption of 12 different types of food as listed above. With respect to change in food consumption behavior, we used three behavioral patterns: increased, decreased, or no change to capture people's reaction following the 2008 price rise and over time. For each pattern, we developed a model. A total of three models were developed. Model 1 deals with increase in consumption of food due to price rise and over time. Model 2 deals with decrease in consumption of food due to price rise and over time. For Model 3 there was no change in consumption of food due to price increase or over time. Table 2 presents a summary of the demographic and socio-economic characteristics of the respondents and respondent households. 
Table 2. Summary data on participants.

\begin{tabular}{|c|c|c|c|c|c|c|c|}
\hline & & \multicolumn{6}{|c|}{ City } \\
\hline & & \multicolumn{2}{|c|}{$\begin{array}{c}\text { Bamenda (Low } \\
\text { Global Integration) }\end{array}$} & \multicolumn{2}{|c|}{$\begin{array}{c}\text { Buea (Medium } \\
\text { Global Integration) }\end{array}$} & \multicolumn{2}{|c|}{$\begin{array}{c}\text { Douala (High } \\
\text { Global Integration) }\end{array}$} \\
\hline & & $\%$ & Mean & $\%$ & Mean & $\%$ & Mean \\
\hline \multirow{3}{*}{ Wealth Ranking } & Low Income & 34.0 & & 13.0 & & 38.0 & \\
\hline & Middle Income & 59.0 & & 53.0 & & 54.0 & \\
\hline & Upper Middle Income & 7.0 & & 34.0 & & 8.0 & \\
\hline \multicolumn{2}{|c|}{ Weighted Educational Index } & & 0.47 & & 0.54 & & 0.47 \\
\hline \multicolumn{2}{|c|}{ Total Household Expenditure (US\$) } & & 508.99 & & 1140.23 & & 514.55 \\
\hline Household & Low HDDS $1-4$ & 30.0 & & 9.0 & & 11.0 & \\
\hline Dietary Diversity & Medium HDDS 5-8 & 51.0 & & 50.0 & & 61.0 & \\
\hline Score Ranking & High HDDS 9-12 & 19.0 & & 41.0 & & 28.0 & \\
\hline \multirow{2}{*}{$\begin{array}{c}\text { Gender of } \\
\text { Respondent }\end{array}$} & Female & 30.0 & & 53.0 & & 50.0 & \\
\hline & Male & 70.0 & & 47.0 & & 50.0 & \\
\hline \multirow{7}{*}{$\begin{array}{l}\text { Age Range of } \\
\text { Respondent }\end{array}$} & Under 18 years old & 9.2 & & 5.2 & & 8.2 & \\
\hline & $18-24$ years old & 16.3 & & 8.2 & & 17.3 & \\
\hline & $25-34$ years old & 27.6 & & 34.0 & & 33.7 & \\
\hline & $35-44$ years old & 23.5 & & 28.9 & & 26.5 & \\
\hline & $45-54$ years old & 12.2 & & 18.6 & & 9.2 & \\
\hline & 55-64 years old & 5.1 & & 3.1 & & 4.1 & \\
\hline & 65 years or older & 6.1 & & 2.1 & & 1.0 & \\
\hline \multirow{5}{*}{$\begin{array}{c}\text { Work Status of } \\
\text { Respondent }\end{array}$} & Working full-time & 68.8 & & 68.6 & & 66.7 & \\
\hline & $\begin{array}{l}\text { Working part-time } \\
\quad \text { or casual }\end{array}$ & 6.3 & & 17.6 & & 13.6 & \\
\hline & Not working and looking & 8.3 & & 3.9 & & 8.6 & \\
\hline & $\begin{array}{l}\text { Not working and } \\
\text { not looking }\end{array}$ & 16.7 & & 9.8 & & 9.9 & \\
\hline & Other & 0.0 & & 0.0 & & 1.2 & \\
\hline
\end{tabular}

\section{Results}

\subsection{Household Demographic Characteristics and Reported Intent to Riot Due to Future Food Price Rises}

When asked whether they would riot in the event of a food price increase, over $70 \%$ of the respondents said yes.

Table 3 explores the relationships between household demographic characteristics and reported willingness to engage in a food riot. What is important about these data is that this reported propensity to riot is nearly the same for almost all demographic groups. Chi-squared tests only show significant propensity to riot among groups classified by city of residence and level of satisfaction with the government $(p<0.05)$. (No other household demographic characteristics were found to be relevant.) Among residents of different cities more people in Douala, which is most integrated into global markets and with the least ability to produce their own food, admitted that they would likely riot if food prices went up. Bamenda, which is least integrated in global markets and with the best ability to provide for themselves, had lower propensity to riot than Douala but had slightly more participants 
who reported being willing to go on riot than Buea. Buea is the middle case in terms of market integration and ability to produce locally. The slight difference between Bamenda and Buea may be explained by the fact that Bamenda has, since the advent of multiparty politics in Cameroon in the early 1990s, been the seat of the main opposition party in Cameroon, the Social Democratic Front (SDF). These results are largely reflective of the fact that in February 2008, Douala witnessed the most violent of the food riots in Cameroon, with official estimates of about 20 deaths [38].

Table 3. Key characteristics of participant and their propensity to riot.

\begin{tabular}{|c|c|c|}
\hline Variables & Subgroup & $\begin{array}{l}\text { Percentage (number) of respondent who } \\
\text { answered "yes" to question "would you } \\
\text { riot in the case of a food price rise?" }\end{array}$ \\
\hline \multirow{3}{*}{ City * } & Bamenda & $65.0 \%(65)$ \\
\hline & Buea & $61.0 \%(61)$ \\
\hline & Douala & $86.0 \%(86)$ \\
\hline \multirow{3}{*}{ Wealth Ranking } & Low Income & $76.5 \%(65)$ \\
\hline & Middle income & $68.1 \%(113)$ \\
\hline & Upper Middle Income & $69.4 \%(34)$ \\
\hline \multirow{2}{*}{ Gender of Participant } & Female & $74.4 \%(99)$ \\
\hline & Male & $67.7 \%(113)$ \\
\hline \multirow{7}{*}{ Age range of Participant } & Under 18 years old & $59.1 \%(13)$ \\
\hline & $18-24$ years old & $75.6 \%(31)$ \\
\hline & 25-34 years old & $68.8 \%(64)$ \\
\hline & $35-44$ years old & $76.6 \%(59)$ \\
\hline & $45-54$ years old & $74.4 \%(29)$ \\
\hline & $55-64$ years old & $50.0 \%(6)$ \\
\hline & 65 years or older & $66.7 \%(6)$ \\
\hline \multirow{5}{*}{ Work status of Participant } & Working full-time & $78.7 \%(96)$ \\
\hline & Working part-time or casual & $65.2 \%(15)$ \\
\hline & Not working and looking & $92.3 \%(12)$ \\
\hline & Not working and not looking & $66.7 \%(14)$ \\
\hline & Other & 0.0 \\
\hline \multirow{9}{*}{$\begin{array}{c}\text { Highest level of education } \\
\text { of Participant }\end{array}$} & No formal schooling & $50.0 \%(3)$ \\
\hline & Some Primary & $63.6 \%(7)$ \\
\hline & Primary completed Junior or Senior & $68.2 \%(30)$ \\
\hline & Some high school & $78.9 \%(45)$ \\
\hline & High school completed & $75.4 \%(43)$ \\
\hline & $\begin{array}{l}\text { Post secondary qualifications } \\
\text { not university diploma, } \\
\text { or degree from college }\end{array}$ & $85.2 \%(23)$ \\
\hline & Some university & $76.5 \%(13)$ \\
\hline & University completed & $54.0 \%(27)$ \\
\hline & Post-graduate MA or MSc or PhD & $73.7 \%(14)$ \\
\hline \multirow{5}{*}{$\begin{array}{l}\text { How happy are you about } \\
\text { the current political } \\
\text { situation is in the country? } *\end{array}$} & Very happy & $100.0 \%(9)$ \\
\hline & Happy & $84.1 \%(37)$ \\
\hline & Neither happy nor unhappy & $56.6 \%(30)$ \\
\hline & Unhappy & $69.4 \%(84)$ \\
\hline & Very unhappy & $75.9 \%(44)$ \\
\hline
\end{tabular}


To triangulate this result, we asked survey respondents to tell us where in Cameroon (location/city), they think people are most likely to riot and why. The responses to this question indicated that most people believe that large urban centers are most likely to be the focus of food riots given that residents are reliant on markets for food access. In particular, Douala was identified as the most likely location for riots. Several examples of quotes from the survey transcripts on responses to this question highlight this perception. For instance, one male survey respondent from Buea, noted that:

"Yaounde (national capital), Douala, Bamenda because these cities are witnessing an increase in population yet there are no job opportunities and (there has been) a very rapid increase in foodstuff prices."

Another male survey respondent from Bamenda concurred:

"Douala, Yaounde, Bafoussam because most of their food items are being imported."

In addition to the dense population present in the major cities, these places were also seen by survey respondents to be the most likely places where riots might occur because of their tendency to oppose the political regime. For instance, when asked what cities would see riots if prices increased, a male focus group participant in Buea noted:

"Douala because it is the economic capital and Bamenda because it is the opposition party capital."

Other survey respondents blamed Cameroon's government for not taking serious actions to ensure affordable food prices and not seeking peaceful solutions to the problems. A female participant from Douala noted:

“(The) Cameroonian government hate(s) peace so if you don't use the hard way (protest), you don't get what you want."

Several other respondents in the survey and participants in the focus group discussions noted that most of the major issues plaguing the food system in Cameroon could be blamed on the government. As one male survey respondent from Douala described:

"The government does not take care of farmers (or) farm to market road networks, and there are heavy taxes on farm produce."

The link between political satisfaction and the propensity to riot is worth examining in details by looking carefully at the numbers and drawing on the insight from our survey and focus group comments. First in terms of the numbers, while $100 \%$ of those who stated that they were happy with the political situation also noted that they would riot, it is important to note that only nine survey participants of the 300 across all three cities noted that they were very happy with the current political situation. Without trying to speculate on why these participants were very happy with political situation and yet would riot, we looked at their responses to the open-end questions in the survey and noted that there was no consistency across all nine respondents. That is, although they were all very happy with the political situation and noted a propensity to riot, some blamed the government for not ensuring low prices and establishing price control while others noted that individuals should take care of themselves and stop relying on the government. The other trend here that is worth exploring further 
is the fact that those who were neither happy nor unhappy had the lowest propensity to riot. A small number of participants fell within this group (30) which highlights political apathy, an issue other authors have explored in more detail $[39,40]$. In brief, the political apathy in Cameroon results from disillusion after recurrent electoral fraud and the fact that same ruling party and president has been holding power since 1982. Unsurprisingly, more than half of those who were not happy with the current political climate in the country stated a willingness to riot. Overall, it is worth noting that over $62 \%$ of all survey respondents were either unhappy or very unhappy with the current political situations in the country.

\subsection{Relationships between Diets/Dietary Changes and Reported Intent to Riot Due to Future Food}

Price Rises

Exploring the link between dietary changes and willingness to riot proved to be methodologically challenging. To assess the link quantitatively, three logit models were developed. The first model dealt with households who indicated that their consumption of different food products had increased; the second model was for those households who indicated that they were now eating less of the different products. The third model was for those who answered that their consumption had not changed. The results of these three models are presented in Table 4.

Table 4. Logit model results.

\begin{tabular}{|c|c|c|c|c|c|}
\hline \multicolumn{2}{|c|}{$\begin{array}{l}\text { M1: Propensity to Riot Due to } \\
\text { Increased Consumption Levels }\end{array}$} & \multicolumn{2}{|c|}{$\begin{array}{l}\text { M2: Propensity to Riot Due to } \\
\text { Decreased Consumption Levels }\end{array}$} & \multicolumn{2}{|c|}{$\begin{array}{l}\text { M3: Propensity to Riot without } \\
\text { Changing Consumption Levels }\end{array}$} \\
\hline Variables & $\begin{array}{c}\text { Coefficient } \\
\text { \& Standard } \\
\text { Error } \\
\end{array}$ & Variables & $\begin{array}{c}\text { Coefficient \& } \\
\text { Standard Error }\end{array}$ & Variables & $\begin{array}{c}\text { Coefficient } \\
\text { \& Standard } \\
\text { Error } \\
\end{array}$ \\
\hline $\begin{array}{c}\text { Weighted } \\
\text { Education Index }\end{array}$ & $\begin{array}{c}-1.914 * \\
(1.002) \\
\end{array}$ & $\begin{array}{c}\text { Total Expenditure } \\
(\mathrm{US} \$)\end{array}$ & $\begin{array}{l}-0.000148 * \\
\left(8.89 \times 10^{-5}\right) \\
\end{array}$ & $\begin{array}{l}\text { Weighted Education } \\
\text { Index }\end{array}$ & $\begin{array}{c}-3.239 * * \\
(1.419) \\
\end{array}$ \\
\hline $\begin{array}{l}\text { Increase in } \\
\text { consumption of } \\
\text { roots due } \\
\text { to price increase } \\
(1=\text { yes, } 0=\text { no })\end{array}$ & $\begin{array}{l}0.854 * \\
(0.461)\end{array}$ & $\begin{array}{l}\text { Weighted } \\
\text { Education Index }\end{array}$ & $\begin{array}{l}-2.791 * \\
(1.460)\end{array}$ & $\begin{array}{l}\text { No change in } \\
\text { consumption of meat } \\
\text { due to price increase } \\
(1=\text { yes, } 0=\text { no })\end{array}$ & $\begin{array}{c}-0.934 * \\
(0.558)\end{array}$ \\
\hline $\begin{array}{c}\text { Increase in } \\
\text { consumption of } \\
\text { vegetables due to } \\
\text { price increase } \\
(1=\text { yes, } 0=\text { no })\end{array}$ & $\begin{array}{c}-0.898 * \\
(0.500)\end{array}$ & $\begin{array}{l}\text { Decrease in } \\
\text { consumption of } \\
\text { pulses due to } \\
\text { price increase } \\
(1=\text { yes, } 0=\text { no })\end{array}$ & $\begin{array}{c}-1.493 * * \\
(0.651)\end{array}$ & $\begin{array}{l}\text { No change in } \\
\text { consumption of eggs } \\
\text { due to price increase } \\
(1=\text { yes, } 0=\text { no })\end{array}$ & $\begin{array}{c}1.408 * * * \\
(0.537)\end{array}$ \\
\hline $\begin{array}{l}\text { Increase in } \\
\text { consumption of } \\
\text { eggs due } \\
\text { to price increase } \\
(1=\text { yes, } 0=\text { no })\end{array}$ & $\begin{array}{c}-1.427 * * * \\
(0.480)\end{array}$ & $\begin{array}{l}\text { Decrease in } \\
\text { consumption of } \\
\text { other food due to } \\
\text { price increase } \\
(1=\text { yes, } 0=\text { no })\end{array}$ & $\begin{array}{l}2.069 * * * \\
(0.704)\end{array}$ & $\begin{array}{c}\text { No change in } \\
\text { consumption of other } \\
\text { food due to price } \\
\text { increase }(1=\text { yes, } 0= \\
\text { no) }\end{array}$ & $\begin{array}{l}-0.941 * \\
(0.525)\end{array}$ \\
\hline $\begin{array}{c}\text { Increase in } \\
\text { consumption of } \\
\text { oil due to } \\
\text { price increase } \\
(1=\text { yes, } 0=\text { no })\end{array}$ & $\begin{array}{l}0.986 * \\
(0.578)\end{array}$ & $\begin{array}{l}\text { Decrease in } \\
\text { consumption of } \\
\text { fruits over time } \\
(1=\text { yes, } 0=\text { no })\end{array}$ & $\begin{array}{c}-2.024 * * \\
(0.867)\end{array}$ & $\begin{array}{l}\text { No change in } \\
\text { consumption of } \\
\text { sugar over time } \\
(1=\text { yes, } 0=\text { no })\end{array}$ & $\begin{array}{c}-1.278 * * \\
(0.519)\end{array}$ \\
\hline
\end{tabular}


Table 4. Cont.

\begin{tabular}{|c|c|c|c|c|c|}
\hline \multicolumn{2}{|c|}{$\begin{array}{l}\text { M1: Propensity to Riot Due to } \\
\text { Increased Consumption Levels }\end{array}$} & \multicolumn{2}{|c|}{$\begin{array}{l}\text { M2: Propensity to Riot Due to } \\
\text { Decreased Consumption Levels }\end{array}$} & \multicolumn{2}{|c|}{$\begin{array}{l}\text { M3: Propensity to Riot without } \\
\text { Changing Consumption Levels }\end{array}$} \\
\hline Variables & $\begin{array}{c}\text { Coefficient } \\
\text { \& Standard } \\
\text { Error }\end{array}$ & Variables & $\begin{array}{c}\text { Coefficient \& } \\
\text { Standard Error }\end{array}$ & Variables & $\begin{array}{c}\text { Coefficient } \\
\text { \& Standard } \\
\text { Error }\end{array}$ \\
\hline $\begin{array}{c}\text { Increase in } \\
\text { consumption of } \\
\text { sugar due to } \\
\text { price increase } \\
(1=\text { yes, } 0=\text { no })\end{array}$ & $\begin{array}{l}1.226 * * \\
(0.606)\end{array}$ & $\begin{array}{l}\text { Decrease in } \\
\text { consumption of } \\
\text { meat over time } \\
(1=\text { yes, } 0=\text { no })\end{array}$ & $\begin{array}{c}1.847 * * \\
(0.739)\end{array}$ & $\begin{array}{l}\text { No change in } \\
\text { consumption of other } \\
\text { foods over time } \\
(1=\text { yes, } 0=\text { no })\end{array}$ & $\begin{array}{l}0.969 * \\
(0.587)\end{array}$ \\
\hline $\begin{array}{c}\text { Increase in } \\
\text { consumption of } \\
\text { other food due to } \\
\text { price increase } \\
(1=\text { yes, } 0=\text { no })\end{array}$ & $\begin{array}{c}-1.297 * * \\
(0.536)\end{array}$ & Constant & $\begin{array}{c}2.317 * * \\
(1.096)\end{array}$ & Constant & $\begin{array}{c}3.590 * * * \\
(1.063)\end{array}$ \\
\hline $\begin{array}{c}\text { Increase in } \\
\text { consumption of } \\
\text { roots over time } \\
(1=\text { yes, } 0=\text { no })\end{array}$ & $\begin{array}{c}-0.899 * * \\
(0.433)\end{array}$ & $\begin{array}{l}\text { Number of } \\
\text { observations }\end{array}$ & 202 & $\begin{array}{l}\text { Number of } \\
\text { observations }\end{array}$ & 202 \\
\hline Constant & $\begin{array}{c}1.934 * * \\
(0.817)\end{array}$ & Pseudo $R^{2}$ & 0.2211 & Pseudo R ${ }^{2}$ & 0.1840 \\
\hline $\begin{array}{l}\text { Number of } \\
\text { observations }\end{array}$ & 270 & & & & \\
\hline Pseudo $\mathrm{R}^{2}$ & 0.1684 & & & & \\
\hline
\end{tabular}

In terms of the demographic factors included in the models, two themes worth highlighting include the fact there is a significant negative relationship between the total household expenditure, which is a proxy for income, and the declared intention to riot if food prices went up. In other words, the higher a household's total expenditures are, the less likely its members would be to riot if prices went up. One way to interpret this is that households who have more disposable income are less likely to react negatively to food price rise. Second there is a significant negative relationship between the weighted education index and the desire to riot when food prices go up. In other words, more educated households are less likely to riot in the advent of rising food prices than less educated households.

In terms of food consumption patterns more specifically, the logit model (Table 4 summarized logit model with significant associations only) highlights several significant results when we looked at the relationships between how research participants might react to price increases and their dietary change. We observed the following differences:

- Based on the 12 food groups that we used to capture dietary trends, the logit model shows that those who had increased their consumption of roots had a higher propensity to riot than those who had not increased their consumption of roots.

- The model also indicates that those who eat more egg even when prices are high had a lower propensity to riot while those who reported no change in consumption of eggs due to price rise had a higher propensity to riot. 
- Those who increased oil consumption had a significantly higher propensity to riot.

- Those who increased their consumption of sugar had a significantly greater propensity to riot, while those who did not change their consumption of sugar had significantly lower propensity to riot.

- Those who decreased their consumption of pulses had lower propensity to riot.

- Households who reported a decrease in the consumption of meat were more likely to indicate a willingness to riot.

- The model also highlights that those who decreased their fruit intake had a lower propensity to riot.

- Finally, the model indicates that there is a relationship between consumption changes in tea, coffee and condiments and riots. Specifically, model results show that those who can afford to increase their consumption of other items such as tea, coffee and condiments are less likely to be dissatisfied and less likely to state that they intend to engage in riots as opposed to those who decreased or maintained their consumption of these items.

The above results do not necessarily indicate a consistent trend for example, where changes in the consumption of locally produced food would show different propensity to riot versus changes in the consumption of imported food. In some cases, one could forward the local food system explanation, proposing that the reason why a decrease in fruits and pulses consumption, both locally produced foods, would lead to lower propensity to riot. By suggesting that consumers might not see the increase in price for these foods, fruits and pulses, as an issue, which has other causes beyond seasonality. This type of argument also holds for changes with other foodstuffs such as oil and sugar, which are related to an increase in the propensity to riot. A major proportion of locally consumed vegetable oil and sugar are imported with their prices are heavily dependent on import duties. Thus the government could be seen as partly responsible for keeping the prices of oil and sugar under control.

An important insight we sort to gather from both the surveys and focus groups as noted in the methodology section was household food preferences, which is different from what people often consumed captured in the dietary survey. We were able to compare the two data sets, noting the fact that there was high consumption and preference for cereals, especially rice and maize, more so than any other food groups. The stories around cereals were both positive, in that many people said they like eating them in diverse forms and negative as some participants expressed dissatisfaction and frustration with high food prices that have led them to have a less varied and mostly cereal-based diet. As one male focus group participant noted when asked how diets had changed over time:

"What do you expect of someone who eats only rice, rice, rice? Let prices drop for us to start eating at least different forms of food my diet is poor."

Another female survey respondent noted in frustration that:

"I am constipated because the balanced diet I used to have before is not more there. Bread every day is too much. I want to eat my normal food so I need that prices should drop."

This sense of frustration with dietary patterns ran through the conversations in the focus groups. Rice and bread and to some extent, maize in areas where the traditional diet is not maize based are now seen as the dominant last resort foodstuff. As one female focus group participant in Buea noted: 
"When things are difficult, I look for different types of food like rice as food to fill the food gaps."

The versatility of rice and maize, in that they can be cooked in several forms, such as boiled accompanied with diverse types of sauces, ground into four and consumed with a variety of sauces and relishes made these foods particularly attractive to many. As one female focus group participant in Buea noted:

"Even though where I am from (ethnicity) we eat mostly fufu (pounded cocoyams) now in my house we eat mostly rice or corn. You can grind them and eat with ngama-ngama (vegetable relish). Corn can be cooked with beans to make cornchaff or you can make pap (warm porridge of fresh corn), while rice you can make jelloff or even njanga rice (fried rice with crayfish)."

Cereals are, therefore, central to understanding the relationship between food consumption and riots as participants indicated strong preference in the survey for rice as a food item and cereal as a food group. This could largely explain why, when cereal prices rose in Cameroon in 2007/08, people could no longer afford even what is considered last resort foodstuffs pushing this frustration to moral and political outrage at the system that was preventing them from basic access.

\section{Discussion}

Overall, our results point to the following key trends:

(1) A huge proportion (70.7\%) of our participants said they would riot if prices rose again, representing people from all cities, age groups, gender, marital status, socio-economic class, and educational levels.

(2) When confronted with a food price increase we noted that households in Cameroon's major cities are more likely to riot than the citizens of cities where people were less reliant on markets for food provisioning.

(3) The impact of diets on people's propensity to riots varies from one food group to the other when we look at the quantitative data, although the qualitative data from surveys and focus groups suggest a prevalent cereal based diet, which could shape propensity to riot.

There is evidence of a strong sense of dissatisfaction of the current political situation in the country among the participants. Further, participants often linked food price increase to a failure of the government to ensure food access, through better farm to market road, price control mechanism, and investment in agriculture. Although in some cases the statistical strength of these relationships is weak, the fact that this presents a consistent picture that is triangulated through both qualitative and quantitative data gives us some confidence as to the robustness of these conclusions. As a result, we tentatively conclude that it is relatively disadvantaged households in the major cities (and in particular, it may be cities that are more integrated into global trading systems and least able to produce their own food), who are most likely to respond to food price rises by taking to the streets in violent protest. Our quantitative analysis, highlights the fact that survey respondents in Douala had a higher propensity to riot than other cities and similarly the insights from the survey and focus group 
suggest that people believe that residents of the major cities such as Douala and Yaoundé are most likely to have a higher propensity to riot than other areas. Coupled with the fact that these cities could be the first spaces exposed to higher prices given that residents are heavily dependent on markets, Douala was also seen as an area that harbors deep political dissatisfaction with the current ruling elite and as such a protest against food price hike could serve as an outlet to express political views. These results are consistent with the literature [2,4] that demonstrates political dissatisfaction is often a key driver of food riots and that urban centers that are more integrated within the global food system experience more price transmission and could be more vulnerable to food riots.

One contribution of this paper, therefore, is to reinforce and provide additional empirical evidence in support of, the conclusions made by Demarest [41] and Hossain and Kalita [42] whose finding suggests that a clear understanding of the local context including the political, economic, and social factors, especially in terms of what people view as the responsibility of their government to act to address the situation, is central in understanding why certain societies experience food riots. However, the analysis in this paper goes a step further, and the logistic regression model also quantifies the importance of both education (through the WEI) and the total household expenditure as important variables that need to be assessed in order to understand who is likely to riot.

A second, and related, contribution of this study is that we demonstrate that the significance of these relationships are contingent on other factors, such as the city and the dietary patterns of the households. Hence, we would like to stress that the evidence we have presented does not suggest that there are direct or simple relations between these variables. As a consequence, this paper should be seen as also contributing to the growing body of literature that attempts to study complex social ecological systems where the effort is increasingly focused on understanding trajectories or pathways rather than simple cause and effect relations $[43,44]$.

Third, we could not find any statistically significant relationship between other demographic factors such as age, gender, work status, and whether participants noticed price increases or not with a propensity to riot. Although these factors feature in reports about food riots, including the recent literature on food riots in SSA that highlight presence of excitable underemployed youth as a key factor [45] or the New York riots which highlight Jewish housewives as the rioters [23]. This difference in findings highlights a core challenge around predicting human behavior especially when it comes to spontaneous events such a riots, as those who might have indicated in our survey that they would riot might not necessarily be those who engage in future protest.

Finally, while this paper provides an empirical starting place in the exploration of diet and riots, it is essential to go further to explore dietary trends and note which foodstuffs people are most sensitive to their price changes. In terms of our data, the qualitative insights highlight that rice was particularly recurrent when our participants talked about their food experiences. The recorded popularity of rice in people's diets in urban Cameroon explains why the government thought that an appropriate response to riots that hit Cameroon in February 2008 would be to target rice prices by lifting the import taxes on rice (as well as flour and fish). The dependence on imported rice is not unique to Cameroon; as Moseley [46] notes by the early 2000s, West African was importing 40\% of the rice that it consumed. Cheap rice imports from Asia, facilitated by World Bank-imposed tariff reductions in West Africa, became an inexpensive source of calories for West African urban dwellers [46]. These trends have seemingly left Cameroonians extremely vulnerable to global rice prices fluctuations and production 
trends in Asia. As a result, it is unsurprising that since 2008, there have been renewed calls for increased investment in local rice production across more of SSA to satisfy growing urban demand $[47,48]$.

\section{Conclusions}

In conclusion, we would like to summarize our insights as follows: the data we collected in Cameroon illustrate that $70 \%$ of the participants $(n=300)$ noted that they would riot in the future if food prices went up and that households who live in major cities but who are not particularly well educated or well off are the most likely to riot over rising food prices. However, our data also demonstrate that many of the relationships discussed in this paper are contingent on a range of local factors. The dependent nature of these relationships is such that trends do not hold even from one city to the next within the same country. Developing proactive policies to reduce the likelihood of violent protest over food prices, therefore, is very challenging. We can only imagine that the policies that work in one region may have no effect, or even a negative, effect in another region. However, as we look to a future where a combination of population growth and climate change are likely to make international commodity markets more volatile, understanding these dynamics becomes ever-more pressing. Hence, we believe that studies such as this one represent the beginning of an emerging and important area of inquiry and we urge scholars, policymakers, and funding agencies to investigate the ways that socioeconomic factors may create a predisposition to food rioting. Dietary patterns and changes should be an important aspect of these investigations because a clear understanding of what foodstuffs or types could likely trigger a larger negative reaction within a community could go a long way in preventing future civil conflict.

\section{Acknowledgments}

This project was funded by Canada's SSHRC through the Canada Research Chair Programme and a SSHRC Insight Development Grant. Thanks to our research assistants in Cameroon and the participants who generously participated in this project.

\section{Author Contributions}

Alexander Legwegoh and Evan Fraser conceived and designed the project; Philip Antwi-Agyei reviewed and commented on the study design and methodology; Krishna Bahadur KC and Alexander Legwegoh analyzed the data; Alexander Legwegoh, Evan Fraser, Krishna Bahadur KC, and Philip Antwi-Agyei co-wrote the paper.

\section{Conflicts of Interest}

The authors declare no conflict of interest.

\section{References}

1. Berazneva, J.; Lee, D.R. Explaining the African food riots of 2007-2008: An empirical analysis. Food Policy 2013, 39, 28-39.

2. Bush, R. Food riots: Poverty, power and protest. J. Agrar. Chang. 2010, 10, 119-129. 
3. Lagi, M.; Bertrand, K.Z.; Bar-Yam, Y. The food crises and political instability in North Africa and the Middle East, 2011. Available online: http://dx.doi.org/10.2139/ssrn.1910031 (accessed on 17 October 2015).

4. Sneyd, L.Q.; Legwegoh, A.; Fraser, E.D. Food riots: Media perspectives on the causes of food protest in Africa. Food Secur. 2013, 5, 485-497.

5. Hendrix, C.S.; Haggard, S. Global food prices, regime type, and urban unrest in the developing world. J. Peace Res. 2015, 52, 143-157.

6. Smith, T.G. Feeding unrest disentangling the causal relationship between food price shocks and sociopolitical conflict in urban Africa. J. Peace Res. 2014, 51, 679-695.

7. Natalini, D.; Jones, A.W.; Bravo, G. Quantitative assessment of political fragility indices and food prices as indicators of food riots in countries. Sustainability 2015, 7, 4360-4385.

8. Brinkman, H.; de Pee, S.; Sanogo, I.; Subran, L.; Bloem, M. High food prices and the global financial crisis have reduced access to nutritious food and worsened nutritional status and health. J. Nutr. 2010, 140, 1535-1615.

9. Hillocks, R. Addressing the yield gap in sub-saharan Africa. Outlook Agric. 2014, 43, 85-90.

10. Rakotoarisoa, M.; Iafrate, M.; Paschali, M. Why Has Africa Become A Net Food Importer Explaining Africa Agricultural and Food Trade Deficits; FAO: Rome, Italy, 2011.

11. FAOSTAT. Consumer prices, food indices. In FAOSTAT; Food And Agriculture Organization of The United Nations Statistics Division: Rome, Italy, 2015.

12. The World Bank Group. Food riot radar. Available online: http://www.worldbank.org/ en/topic/poverty/food-price-crisis-observatory-4 (accessed on 13 July 2014).

13. Grote, U. Can we improve global food security? A socio-economic and political perspective. Food Secur. 2014, 6, 187-200.

14. Goldstone, J.A. The comparative and historical study of revolutions. Annu. Rev. Sociol. 1982, 8, 187-207.

15. Goldstone, J.A. Revolution and Rebellion in the Early Modern World; University of Carlifornia Press: Oakland, CA, USA, 1991.

16. Goldstone, J.A. Toward a fourth generation of revolutionary theory. Annu. Rev. Political Sci. 2001, 4, 139-187.

17. Goldstone, J.A. Comparative historical analysis and knowledge accumulation in the study of revolutions. In Comparative Historical Analysis in the Social; Mahoney, J.; Rueschemeyer, D., Eds.; Cambridge University Press: Cambridge, UK, 2003; pp. 41-90.

18. Goldstone, J.A. Understanding the revolutions of 2011: Weakness and resilience in Middle Eastern autocracies. Foreign Aff. 2011, 90, 8-16.

19. Padmanabhan, S.Y. The great bengal famine. Annu. Rev. Phytopathol. 1973, 11, 11-24.

20. Webb, P.; Braun, J.V.; Yohannes, Y. Famine in Ethiopia: Policy Implications of Coping Failure at National and Household Levels; International Food Policy Research Institute: Washington, DC, USA, 1992; Volume 29.

21. O'Brien, T. Food riots as representations of insecurity: Examining the relationship between contentious politics and human security. Confl. Secur. Dev. 2012, 12, 31-49.

22. Bentley, A. Eating for Victory: Food Rationing and the Politics; University of Illinois Press: Champain, IL, USA, 1998. 
23. Frank, D. Housewives, socialists, and the politics of food: The 1917 new york cost-of-living protests. Fem. Stud. 1985, 11, 255-285.

24. Dinmore, G. Italians Spurn Pasta in Price Protest. Financial Times, 14 September 2007. Available online: http://www.ft.com/cms/s/0/3167ab08-625a-11dc-bdf6-0000779fd2ac.html?from=food_ multimedia (accessed on 17 October 2015).

25. García-Salazar, J.A.; Skaggs, R.; Crawford, T.L. Procampo, the Mexican corn market, and mexican food security. Food Secur. 2011, 3, 383-394..

26. Patel, R. Food riots. Int. Encycl. Revolut. Protest. 2009, doi:10.1111/ b.9781405184649.2009.00571.x.

27. Lévi-Strauss, C. The culinary triangle. In Food Culture: A Reader; Routledge: London, UK, 1997.

28. Howe, K.R. Mixed methods, triangulation, and causal explanation. J. Mixed Methods Res. 2012, 6, 89-96.

29. Torrance, H. Triangulation, respondent validation, and democratic participation in mixed methods research. J. Mixed Methods Res. 2012, 6, 111-123.

30. UN-Habitat. Cameroon un-habitat data. In Download UN-Habitat Data Collections; UN Habitat: Nairobi, Kenya, 2015.

31. Bopda, A.P.; Awono, L. Institutional development of urban agriculture-An ongoing history of yaoundé. In African Urban Harvest; Springer: New York, NY, USA, 2010.

32. Kennedy, G.; Berardo, A. Proxy measures of household food consumption for food security assessment and surveillance: Comparison of the household dietary diversity and food consumption. Public Health Nutr. 2010, 13, 2010-2018.

33. Swindale, A.; Bilinsky, P. Household Dietary Diversity Score (hdds) for Measurement of Household Food Access: Indicator Guide; Food and Nutrition Technical Assistance III Project (FANTA): Washington, DC, USA, 2006.

34. KC, K.B. Combining Socio-Economic and Spatial Methodologies in Rural Resources and Livelihood Development: A Case from Mountains of Nepal; Margraf: Chiampo, Italy, 2005.

35. IBM Corp. IBM SPSS Statistics for Windows; IBM Corp.: Armonk, NY, USA, 2013.

36. StataCorp. Stata Statistical Software; StataCorp LP: College Station, TX, USA, 2013.

37. Researchware Inc. Hyperresearch 3.7.2, Software; ResearchWare, Inc.: Randolph, MA, USA, 2015. Available online: http://www.researchware.com/products/hyperresearch.html (accessed on 17 October 2015).

38. Amin, J.A. Understanding the protest of February 2008 in Cameroon. Africa Today 2012, 58, $20-43$.

39. Ngwane, G. Opposition politics and electoral democracy in Cameroon, 1992-2007. Afr. Dev. 2015, 39, 103-116.

40. Nyamnjoh, F.B. Cameroon: Over twelve years of cosmetic democracy. News Nord. Afr. Inst. 2002, 3, 5-8.

41. Demarest, L. Food price rises and political instability: Problematizing a complex relationship. Eur. J. Dev. Res. 2014, doi:10.1057/ejdr.2014.52.

42. Hossain, N.; Kalita, D. Moral economy in a global era: The politics of provisions during contemporary food price spikes. J. Peasant Stud. 2014, 41, 815-831.

43. Fraser, E.D. Travelling in antique lands: Using past famines to develop an adaptability/resilience framework to identify food systems vulnerable to climate change. Clim. Chang. 2007, 83, 495-514. 
44. Homer-Dixon, T. Strategies for studying causation in complex ecological-political systems. J. Environ. Dev. 1996, 5, 132-148.

45. Raleigh, C.; Choi, H.J.; Kniveton, D. The devil is in the details: An investigation of the relationships between conflict, food price and climate across Africa. Glob. Environ. Chang. 2015, 32, 187-199.

46. Moseley, W.G.; Carney, J.; Becker, L. Neoliberal policy, rural livelihoods, and urban food security in West Africa: A comparative study of the Gambia, côte d'ivoire, and mali. Proc. Natl. Acad. Sci. USA 2010, 107, 5774-5779.

47. Naseem, A.; Mhlanga, S.; Diagne, A.; Adegbola, P.Y.; Midingoyi, G.S.-K. Economic analysis of consumer choices based on rice attributes in the food markets of West Africa-The case of benin. Food Secur. 2013, 5, 575-589.

48. Saito, K.; Dieng, I.; Toure, A.A.; Somado, E.A.; Wopereis, M.C. Rice yield growth analysis for 24 African countries over 1960-2012. Glob. Food Secur. 2015, 5, 62-69.

(C) 2015 by the authors; licensee MDPI, Basel, Switzerland. This article is an open access article distributed under the terms and conditions of the Creative Commons Attribution license (http://creativecommons.org/licenses/by/4.0/). 